\title{
Impact of genotype on endocrinal complications in $\beta$-thalassemia patients
}

\author{
AHMED AL-AKHRAS $^{1}$, MOHAMED BADR $^{1}$, USAMA EL-SAFY ${ }^{1}$, ELISABETH KOHNE ${ }^{2}$, TAMER HASSAN $^{1}$, \\ HADEEL ABDELRAHMAN $^{1}$, MOHAMED MOURAD ${ }^{3}$, JOAQUIN BRINTRUP ${ }^{2}$ and MARWA ZAKARIA ${ }^{1}$ \\ ${ }^{1}$ Department of Pediatrics, Zagazig University, Zagazig 44111, Egypt; \\ ${ }^{2}$ Department of Pediatrics and Adolescents, Laboratory of Hemoglobinopathy, University of Ulm, \\ D-89069 Ulm, Germany; ${ }^{3}$ Department of Clinical Pathology, Zagazig University, Zagazig 44111, Egypt
}

Received November 23, 2015; Accepted February 18, 2016

DOI: $10.3892 /$ br.2016.646

\begin{abstract}
In $\beta$-thalassemia, certain mutations cause a complete absence of $\beta$-globin chain synthesis, termed $\beta^{0}$-thalassemia, while others may allow certain $\beta$-globin production and are termed $\beta^{+}$- or $\beta^{++}$-thalassemia. The homozygous state results in severe anemia, which requires regular blood transfusion. By contrast, frequent blood transfusion can in turn lead to iron overload, which may result in several endocrinal complications. The present study aimed to investigate the impact of genotype on the development of endocrine complications in $\beta$-thalassemia patients. A cross-sectional study was conducted on 100 thalassemia patients $>10$ years. A data abstraction form was designed to capture the appropriate information from the individual medical records, including full clinical, laboratory, transfusion and chelation data. The genotype of the patients was identified by the DNA sequencing technique. Growth retardation and hypogonadism were the most prominent endocrinal complications (70 and 67\%, respectively) followed by hypothyroidism, diabetes mellitus and hypoparathyrodism ( 8,8 and $7 \%$, respectively). The most common mutations identified were IVS-1-110, IVS-1-1 and IVS-1-6 (63, 47 and $41 \%$, respectively). Patients with the $\beta^{0} \beta^{0}$ genotype had a significantly higher prevalence of growth retardation, hypogonadism, hypothyroidism and hypoparathyrodism compared to those with the $\beta^{0} \beta^{+}$and $\beta^{+} \beta^{+}$genotypes $(\mathrm{P}<0.001$, $\mathrm{P}<0.001, \mathrm{P}<0.001$ and $\mathrm{P}=0.037$, respectively). Patients with the homozygous IVS-11-745 mutation had a significantly higher prevalence of diabetes $(\mathrm{P}=0.001)$. The underlying genetic defect in thalassemia patients is a contributing factor for the development of endocrinal complications, as patients with the
\end{abstract}

Correspondence to: Dr Tamer Hassan, Department of Pediatrics, Zagazig University, Zagazig University Street 1, Zagazig 44111, Egypt

E-mail: dr.tamerhassan@yahoo.com

Abbreviations: DFO, desferrioxamine; DFP, deferiprone; DFX, deferasirox; IVS, intervening sequence; $\mathrm{C}$, codon

Key words: thalassemia, genotype, endocrinal more severe defects have a greater rate of iron loading through higher red cell consumption.

\section{Introduction}

The $\beta$-thalassemias are a group of recessively inherited hemoglobin disorders characterized by reduced synthesis of $\beta$-globin chains (1). The severity of clinical manifestation and laboratory findings in thalassaemia largely depends on the type of underlying mutations of the $\beta$-globin gene, which are mostly point mutations or gene deletions (2). When no $\beta$-chains are produced $\left(\beta^{0}\right)$ an excess amount of $\alpha$-globin chains results in the destruction of the red cell precursors in the bone marrow. In cases where there is some production of $\beta$-globin chain $\left(\beta^{+} \beta^{++}\right)$, the chain imbalance will be less, resulting in milder clinical phenotype (3). The homozygotes or compound heterozygote patients for $\beta$-thalassemia depend on frequent transfusions for life (4).

However, as a result of hypertransfusion therapy and increased longevity, iron tissue toxicity has become more common, and contributes significantly to morbidity in these patients (5). Despite intensive chelating therapy, growth retardation, hypogonadotrophic hypogonadism, diabetes mellitus, hypothyroidism and hypoparathyrodism represent the most common endocrinopathies in thalassemic patients (6). Data from a previous study suggests that the genotype, which determines the clinical severity of the disease, may also be a contributing factor in the development of such complications (7). The present study aimed to identify the association between genotype and endocrine complications in patients with $\beta$-thalassemia.

\section{Materials and methods}

General. A cross-sectional study was conducted on 100 thalassemic patients (54 males and 46 females) with a mean age of 14.2 \pm 1.37 years (range, 12-18 years), who were registered in and followed up at the Pediatric Hematology Unit of Zagazig University Hospital (Zagazig, Egypt) between July 2011 and June 2013. The data abstraction form was designed to capture the appropriate information, and the collected data included: Full clinical information including age, gender and age at 
Table I. Association between growth retardation and each of the demographic, transfusion, chelation characteristics, compliance and serum ferritin level.

\begin{tabular}{|c|c|c|c|c|c|}
\hline \multirow[b]{2}{*}{ Characteristics } & \multirow[b]{2}{*}{ Patients, $\mathrm{n}$} & \multicolumn{2}{|c|}{ Growth retardation $(\mathrm{n}=100)$} & \multirow[b]{2}{*}{$\chi^{2}$ test } & \multirow[b]{2}{*}{ P-value } \\
\hline & & Negative $(\mathrm{n}=30), \mathrm{n}(\%)$ & Positive $(\mathrm{n}=70), \mathrm{n}(\%)$ & & \\
\hline Age, years & & & & 5.74 & $0.016^{\mathrm{a}}$ \\
\hline$\leq 14$ & 66 & $25(37.9)$ & $41(62.1)$ & & \\
\hline$>14$ & 34 & $5(14.7)$ & $29(74.3)$ & & \\
\hline Gender & & & & 0.01 & 0.9 \\
\hline Male & 54 & $16(29.6)$ & $38(70.4)$ & & \\
\hline Female & 46 & $14(30.4)$ & $32(69.6)$ & & \\
\hline Age of start transfusion, months & & & & 11.98 & $<0.001^{\mathrm{b}}$ \\
\hline$\leq 9$ & 68 & $13(19.1)$ & $55(80.9)$ & & \\
\hline$>9$ & 32 & $17(53.1)$ & $15(46.9)$ & & \\
\hline Frequency of transfusion, weeks & & & & 15.39 & $<0.001^{\mathrm{b}}$ \\
\hline Every 2-3 & 43 & $4(9.3)$ & $39(90.7)$ & & \\
\hline Every 4-5 & 57 & $26(45.6)$ & $31(54.5)$ & & \\
\hline Age of start chelation, years & & & & 28.70 & $<0.001^{\mathrm{b}}$ \\
\hline$\leq 3$ & 73 & $11(15.1)$ & $62(84.9)$ & & \\
\hline$>3$ & 27 & $19(70.4)$ & $8(29.6)$ & & \\
\hline Type of chelators & & & & 7.59 & 0.055 \\
\hline DFX & 19 & $9(47.4)$ & $10(52.6)$ & & \\
\hline DFP & 40 & $11(27.5)$ & $29(72.5)$ & & \\
\hline DFO & 31 & $5(16.1)$ & $26(83.9)$ & & \\
\hline $\mathrm{DFO}+\mathrm{DFP}$ & 10 & $5(50.0)$ & $5(50.0)$ & & \\
\hline Compliance, $\%$ & & & & 9.90 & $0.0015^{\mathrm{a}}$ \\
\hline$<60$ & 69 & $14(20.3)$ & 55 (79.7) & & \\
\hline$\geq 60$ & 31 & $16(51.6)$ & $15(48.4)$ & & \\
\hline $\begin{array}{l}\text { Mean serum ferritin level } \pm \mathrm{SD} \\
\text { (range) }, \mathrm{ng} / \mathrm{ml}\end{array}$ & & $2,227.8 \pm 796.1(836-5,000)$ & $4,155.9 \pm 1,841.3(1,026-8,500)$ & 5.50 & $<0.001^{\mathrm{b}}$ \\
\hline
\end{tabular}

${ }^{\mathrm{a}} \mathrm{P}<0.05 ;{ }^{\text {b }}<0.001$. DFX, deferasirox; DFP, deferiprone; DFO, desferrioxamine; SD, standard deviation.

diagnosis; transfusion data including age of start transfusion and frequency of transfusion; chelation data including age of start chelation, type of iron chelators and compliance; physical examination with special emphasis on assessment of anthropometric data and assessment of pubertal status in both genders according to the Tanner classification and girl's menstrual status; laboratory data including complete blood count, serum ferritin, fasting blood glucose, basal growth hormone, parathormone, thyroid-stimulating hormone (TSH), free T4, luteinizing hormone ( $\mathrm{LH})$, follicle-stimulating hormone (FSH), estradiol (in females) and testosterone (in males) and genotypes of patients were performed using DNA sequencing techniques in Laboratory of Hemoglobinopathies (University of Ulm, Ulm, Germany).

Treatment protocol. All the patients followed a standard treatment protocol and were transfused every 2-5 weeks to maintain the pretransfusion hemoglobin level $>9 \mathrm{mg} / \mathrm{dl}$. Patients received either desferrioxamine (DFO) subcutaneously or intravenously at a dose of $30-50 \mathrm{mg} / \mathrm{kg} / \mathrm{day}$ alone or in combination with deferiprone (DFP) at a dose of $50-75 \mathrm{mg} / \mathrm{kg} /$ day. Other patients received DFP alone or deferasirox (DFX) alone in a dose of $20-40 \mathrm{mg} / \mathrm{kg} / \mathrm{day}$ with variable compliance.

Classification of patients according to genotype. Patients were divided into 3 groups according to their genotype based on the $\beta$-globin gene production. Group 1 consisted of 34 patients (34\%) with mutations resulting in no $\beta$-globin chain synthesis $\left(\beta^{0} \beta^{0}\right)$, group 2 included 6 patients $(6 \%)$ with a mutation resulting in a small amount of $\beta$-globin chain synthesis $\left(\beta^{0} \beta^{+}\right)$and group 3 included 60 patients $(60 \%)$ with a mutation resulting in a moderate amount of $\beta$-globin synthesis $\left(\beta^{+} \beta^{+}\right)$.

Definitions. Short stature was defined as patient height $>2$ standard deviation below the mean for age, gender and ethnicity (6). Short stature was evaluated by assessment of patient height and plotted on Egyptian growth charts (source: Cairo University, Diabetic Endocrine and Metabolic Pediatric Unit and the National Research Center, Cairo, Egypt), and measurement of the basal growth hormone level. 
Table II. Association between hypogonadism and each of the demographic, transfusion, chelation characteristics, compliance and serum ferritin level.

\begin{tabular}{|c|c|c|c|c|c|}
\hline \multirow[b]{2}{*}{ Characteristics } & \multirow[b]{2}{*}{ Patients, $\mathrm{n}$} & \multicolumn{2}{|c|}{ Hypogonadism $(n=100)$} & \multirow[b]{2}{*}{$\chi^{2}$ test } & \multirow[b]{2}{*}{ P-value } \\
\hline & & Negative (n=33), n (\%) & Positive (n=67), n (\%) & & \\
\hline Age, years & & & & 5.49 & $0.019^{\mathrm{a}}$ \\
\hline$\leq 14$ & 66 & $27(40.9)$ & $39(59.1)$ & & \\
\hline$>14$ & 34 & $6(17.6)$ & $28(82.4)$ & & \\
\hline Gender & & & & 0.01 & 0.93 \\
\hline Male & 54 & $18(33.3)$ & $36(66.7)$ & & \\
\hline Female & 46 & $15(32.6)$ & $31(67.4)$ & & \\
\hline Age of start transfusion, months & & & & 14.81 & $<0.001^{\mathrm{b}}$ \\
\hline$\leq 9$ & 68 & 14 (20.6) & $54(79.4)$ & & \\
\hline$>9$ & 32 & $19(59.4)$ & 13 (40.6) & & \\
\hline Frequency of transfusion, weeks & & & & 19.16 & $<0.001^{\mathrm{b}}$ \\
\hline Every 2-3 & 43 & $4(9.3)$ & $39(90.7)$ & & \\
\hline Every 4-5 & 57 & $29(50.9)$ & $28(49.1)$ & & \\
\hline Age of start chelation, years & & & & 28.20 & $<0.001^{\mathrm{b}}$ \\
\hline$\leq 3$ & 73 & $13(17.8)$ & $60(82.2)$ & & \\
\hline$>3$ & 27 & $20(74.1)$ & $7(25.9)$ & & \\
\hline Type of chelators & & & & 5.70 & 0.12 \\
\hline DFX & 19 & $9(47.4)$ & $10(52.6)$ & & \\
\hline DFP & 40 & $13(32.5)$ & $27(67.5)$ & & \\
\hline DFO & 31 & $6(19.4)$ & $25(80.6)$ & & \\
\hline DFO+DFP & 10 & $5(50.0)$ & $5(50.0)$ & & \\
\hline Compliance, $\%$ & & & & 9.69 & $0.0018^{\mathrm{a}}$ \\
\hline$<60$ & 69 & $16(23.2)$ & $53(76.8)$ & & \\
\hline$\geq 60$ & 31 & $17(54.8)$ & $14(45.2)$ & & \\
\hline $\begin{array}{l}\text { Mean serum ferritin level } \pm \mathrm{SD} \\
\text { (range), ng/ml }\end{array}$ & & $2,207.2 \pm 755.9(836-5,000)$ & $4,252.4 \pm 1,824.1(1,626-8,500)$ & 6.12 & $<0.001^{\mathrm{b}}$ \\
\hline
\end{tabular}

${ }^{\mathrm{a}} \mathrm{P}<0.05 ;{ }^{\text {b }}<0.001$. DFX, deferasirox; DFP, deferiprone; DFO, desferrioxamine; SD, standard deviation.

Hypogonadotropic hypogonadism is LH and FSH levels $<2 \mathrm{IU} / \mathrm{l}$, with an estradiol concentration of $<20 \mathrm{pg} / \mathrm{ml}$ in females or a testosterone concentration of $<3 \mathrm{ng} / \mathrm{ml}$ in males (7). Hypogonadism was detected by the absence of breast development in females and absence of testicular enlargement in males $(<4 \mathrm{ml})$, as measured by preorchidometer by the age of 16 years $(8)$.

Primary hypothyroidism is a low serum thyroxine with an elevated serum TSH concentration (9). The criteria for diagnosis of hypoparathyroidism were low parathormone level, low total and ionized serum calcium, high serum phosphate, normal serum magnesium and alkaline phosphatase levels (10).

The criteria for diabetes mellitus was based on a family history of diabetes, and if the patient was on treatment with insulin and measurement of fasting blood glucose level according to American Diabetes Association, World Health Organization Criteria and National Diabetes Health Group 1979 (11).

Statistical analysis. Data were assessed, entered and analyzed using SPSS version 20 (IBM SPSS, Armonk, NY, USA). Data are expressed as the mean \pm standard deviation for quantitative variables, number and percentage for qualitative variables. $\chi^{2}$ test and t-test were used when appropriate to compare between different groups. $\mathrm{P}<0.05$ and $\mathrm{P}<0.001$ were considered to indicate statistically significant differences.

Statement of ethics. The present study was conducted in accordance with the ethical standards of the Helsinki Declaration of 1964 as revised in 2000, and was approved by the Institutional Review Board. Informed consent was obtained from the study participant or from their guardians.

\section{Results}

Patient characteristics. The mean age of the patients was $14.2 \pm 1.37$ years with a range of $12-18$ years. There were 54 males and 46 females, with a mean serum ferritin level of $3,577.5 \pm 1,826 \mathrm{ng} / \mathrm{ml}$. In total, $68 \%$ of the patients started blood transfusion $<9$ months and $32 \%$ started blood transfusion $>9$ months. The mean age of start iron chelation was 
Table III. Association between hypothyroidism and each of the demographic, transfusion, chelation characteristics, compliance and serum ferritin level.

\begin{tabular}{|c|c|c|c|c|c|}
\hline \multirow[b]{2}{*}{ Characteristics } & \multirow[b]{2}{*}{ Patients, $\mathrm{n}$} & \multicolumn{2}{|c|}{ Hypothyroidism $(\mathrm{n}=100)$} & \multirow[b]{2}{*}{$\chi^{2}$ test } & \multirow[b]{2}{*}{ P-value } \\
\hline & & Negative (n=92), no. $(\%)$ & Positive (n=8), no. (\%) & & \\
\hline Age, years & & & & 13.83 & $0.001^{\mathrm{b}}$ \\
\hline$\leq 14$ & 66 & $66(100.0)$ & $0(0.0)$ & & \\
\hline$>14$ & 34 & $26(76.5)$ & $8(23.5)$ & & \\
\hline Gender & & & & 0.02 & 0.89 \\
\hline Male & 54 & $50(92.6)$ & $4(7.4)$ & & \\
\hline Female & 46 & $42(91.3)$ & $4(8.7)$ & & \\
\hline Age of start transfusion, months & & & & 4.05 & $0.04^{\mathrm{a}}$ \\
\hline$\leq 9$ & 68 & $60(88.2)$ & $8(11.8)$ & & \\
\hline$>9$ & 32 & $32(100.0)$ & $0(0.0)$ & & \\
\hline Frequency of transfusion, weeks & & & & 9.14 & $0.002^{\mathrm{a}}$ \\
\hline Every 2-3 & 43 & $35(81.4)$ & $8(18.6)$ & & \\
\hline Every 4-5 & 57 & $57(100.0)$ & $0(0.0)$ & & \\
\hline Age of start chelation, years & & & & 1.90 & 0.16 \\
\hline$\leq 3$ & 73 & $65(89.0)$ & $8(11.0)$ & & \\
\hline$>3$ & 27 & $27(100.0)$ & $0(0.0)$ & & \\
\hline Type of chelators & & & & 5.29 & 0.15 \\
\hline DFX & 19 & $19(100.0)$ & $0(0.0)$ & & \\
\hline DFP & 40 & $34(85.0)$ & $6(15.0)$ & & \\
\hline DFO & 31 & $29(93.5)$ & $2(6.5)$ & & \\
\hline DFO+DFP & 10 & $10(100.0)$ & $0(0.0)$ & & \\
\hline Compliance, $\%$ & & & & 3.87 & $0.0049^{\mathrm{a}}$ \\
\hline$<60$ & 69 & $61(88.4)$ & $8(11.6)$ & & \\
\hline$\geq 60$ & 31 & $31(100.0)$ & $0(0.0)$ & & \\
\hline $\begin{array}{l}\text { Mean serum ferritin level } \pm \mathrm{SD} \\
\text { (range) } \mathrm{ng} / \mathrm{ml}\end{array}$ & & $3,247.2 \pm 1,482(836-6,820)$ & $7,376.2 \pm 839.2(5,600-8,500)$ & 7.70 & $<0.001^{\mathrm{b}}$ \\
\hline
\end{tabular}

${ }^{\mathrm{a}} \mathrm{P}<0.05 ;{ }^{\mathrm{b}} \mathrm{P}<0.001$. DFX, deferasirox; DFP, deferiprone; DFO, desferrioxamine; SD, standard deviation.

$2.78 \pm 1.1$ years. A total of $40 \%$ of patients were receiving DFP, $31 \%$ were receiving DFO, $19 \%$ were receiving DFX and $10 \%$ was receiving combined DFO and DFP. The mean compliance was $55.52 \pm 16.2 \%$ with a range of $28-85 \%$.

Growth retardation and hypogonadism were the most common endocrinal complications in the patients (70 and $67 \%$, respectively) followed by hypothyroidism, diabetes mellitus and hypoparathyroidism $(8,8$ and $7 \%$, respectively).

IVS mutations. The most prominent mutations identified in the patients were IVS-1-110, IVS-1-1 and IVS-1-6 (63, 47 and 41\%, respectively), followed by C39 (10.5\%), IVS-11-745 (6\%), promotor $87(3 \%)$, C5 (2\%), C15 (1\%), IVS-1-5 (1\%) and IVS-11-848 (1\%).

Growth retardation in patients. Growth retardation was identified in $74.3 \%$ of patients $>14$ years old and $62.1 \%$ of patients $<14$ years old, and no significant difference was identified between males and females. A total of $78.5 \%$ of patients with growth retardation started earlier blood transfusion ( $<9$ months), 55.7\% received frequent transfusion (every 2-3 weeks), $88.5 \%$ started iron chelation ( $<3$ years) and $78.5 \%$ were poor compliant with high mean serum ferritin level $(4,155.9 \pm 1,841.3 \mathrm{ng} / \mathrm{ml})$ (Table I).

Hypogonadism in patients. Hypogonadism was identified in $82.4 \%$ of patients $>14$ years old and $59.1 \%$ of patients $<14$ years old with no significant difference between males and females. A total of $80.5 \%$ of patients with hypogonadism started earlier transfusion ( $<9$ months), $58.2 \%$ of them received frequent transfusion (every 2-3 weeks). In total, $89.5 \%$ of patients with hypogonadism started iron chelation ( $<3$ years) and $79.1 \%$ had a poor compliance with a high mean serum ferritin level $(4,252.4 \pm 1,824.1 \mathrm{ng} / \mathrm{ml})$, as shown in Table II.

All the patients who developed hypothyroidism were $>14$ years old (4 males and 4 females) and no significant difference was identified between males and females. These patients all started earlier transfusion ( $<9$ months), earlier iron chelation $(<3$ years) as well as frequent blood transfusion (every 2-3 weeks), and $11.6 \%$ had a poor compliant with 
Table IV. Association between diabetes mellitus and each of the demographic, transfusion, chelation characteristics, compliance and serum ferritin level.

\begin{tabular}{|c|c|c|c|c|c|}
\hline \multirow[b]{2}{*}{ Characteristics } & \multirow[b]{2}{*}{ Patients, $\mathrm{n}$} & \multicolumn{2}{|c|}{ Diabetes mellitus $(\mathrm{n}=100)$} & \multirow[b]{2}{*}{$\chi^{2}$ test } & \multirow[b]{2}{*}{ P-value } \\
\hline & & Negative (n=92), n (\%) & Positive $(\mathrm{n}=8), \mathrm{n}(\%)$ & & \\
\hline Age, years & & & & 1.92 & 0.16 \\
\hline$\leq 14$ & 66 & $63(95.5)$ & $3(4.5)$ & & \\
\hline$>14$ & 34 & $29(85.3)$ & $5(14.7)$ & & \\
\hline Gender & & & & 0.02 & 0.89 \\
\hline Male & 54 & $50(92.6)$ & $4(7.4)$ & & \\
\hline Female & 46 & $42(91.3)$ & $4(8.7)$ & & \\
\hline Age of start transfusion, months & & & & 4.05 & $0.04^{\mathrm{a}}$ \\
\hline$\leq 9$ & 68 & $60(88.2)$ & $8(11.8)$ & & \\
\hline$>9$ & 32 & $32(100.0)$ & $0(0.0)$ & & \\
\hline Frequency of transfusion, weeks & & & & 2.35 & 0.12 \\
\hline Every 2-3 & 43 & $37(86.0)$ & $6(14.0)$ & & \\
\hline Every 4-5 & 57 & $55(96.5)$ & $2(3.5)$ & & \\
\hline Age of start chelation, years & & & & 1.90 & 0.16 \\
\hline$\leq 3$ & 73 & $65(89.0)$ & $8(11.0)$ & & \\
\hline$>3$ & 27 & $27(100.0)$ & $0(0.0)$ & & \\
\hline Type of chelators & & & & 5.29 & 0.15 \\
\hline DFX & 19 & $19(100.0)$ & $0(0.0)$ & & \\
\hline DFP & 40 & $34(85.0)$ & $6(15.0)$ & & \\
\hline DFO & 31 & $29(93.5)$ & $2(6.5)$ & & \\
\hline DFO+DFP & 10 & $10(100.0)$ & $0(0.0)$ & & \\
\hline Compliance, $\%$ & & & & 3.87 & $0.04^{\mathrm{a}}$ \\
\hline$<60$ & 69 & $61(88.4)$ & $8(11.6)$ & & \\
\hline$\geq 60$ & 31 & $31(100.0)$ & $0(0.0)$ & & \\
\hline $\begin{array}{l}\text { Mean serum ferritin level } \pm \mathrm{SD} \\
\text { (range), } \mathrm{ng} / \mathrm{ml}\end{array}$ & & $3,336.1 \pm 1,627(836-7,830)$ & $6,353.2 \pm 786.8(3,303-8,500)$ & 4.99 & $<0.001^{\mathrm{b}}$ \\
\hline
\end{tabular}

${ }^{\mathrm{a}} \mathrm{P}<0.05$; ${ }^{\mathrm{P}}<0.001$. DFX, deferasirox; DFP, deferiprone; DFO, desferrioxamine; SD, standard deviation.

a high mean serum ferritin level $(7,376.2 \pm 839.2 \mathrm{ng} / \mathrm{ml})$, as shown in Table III.

Diabetes mellitus in patients. Diabetes mellitus was identified in 8 patients and $62.5 \%$ of them were $>14$ years old with no significant difference identified between males and females. All the patients who developed diabetes mellitus started earlier transfusion ( $<9$ months), earlier iron chelators ( $<3$ years) and $75 \%$ of them received frequent transfusion (every 2-3 weeks) with a poor compliance and high mean serum ferritin level $(6,353.2 \pm 786.8 \mathrm{ng} / \mathrm{ml})$ (Table IV).

Hypoparathyroidism in patients. Hypoparathyroidism was observed in $7 \%$ of the patients and $71.4 \%$ of them were $>14$ years old, with no significant difference identified between males and females. A total of $85.7 \%$ of patients with hypoparathyrodism started earlier transfusion ( $<9$ months) and earlier iron chelators ( $<3$ years). There were $71.4 \%$ of patients with hypoparathyrodism who received frequent transfusion (every 2-3 weeks) and all were poor compliant with a high mean serum ferritin level $(5,952.6 \pm 3,022.6 \mathrm{ng} / \mathrm{ml})$ (Table V).

$\beta^{0} \beta^{0}$ genotype. A total of $94.1 \%$ of patients with the $\beta^{0} \beta^{0}$ genotype started earlier transfusion ( $<9$ months), $85.2 \%$ received frequent transfusion (every 2-3 weeks) and 91.1\% started earlier iron chelators ( $<3$ years). In addition, patients with the $\beta^{0} \beta^{0}$ genotype had a higher prevalence of growth retardation, hypogonadism, hypothyroidism and hypoparathyroidism (94.1, 91.1, 75 and 71\%, respectively) (Table VI).

\section{Discussion}

Endocrine dysfunction is a frequent complication in thalassemic patients who are on regular transfusions. In a previous study, $\leq 66 \%$ of the patients had at least a single endocrine disorder and $40 \%$ have multiple endocrinopathies (9).

Iron overload has for a long time been considered as the major cause of endocrine abnormalities of $\beta$-thalassemia (12). Growth retardation is frequently profound in these children. 
Table V. Association between hypoparathyroidism and each of the demographic, transfusion, chelation characteristics, compliance and serum ferritin level.

\begin{tabular}{|c|c|c|c|c|c|}
\hline \multirow[b]{2}{*}{ Characteristics } & \multirow[b]{2}{*}{ Patients, $\mathrm{n}$} & \multicolumn{2}{|c|}{ Hypoparathyroidism $(\mathrm{n}=100)$} & \multirow[b]{2}{*}{$\chi^{2}$ test } & \multirow[b]{2}{*}{ P-value } \\
\hline & & Negative (n=93), n (\%) & Positive (n=7), n (\%) & & \\
\hline Age, years & & & & 4.65 & $0.03^{\mathrm{a}}$ \\
\hline$\leq 14$ & 66 & $64(97.0)$ & $2(3.0)$ & & \\
\hline$>14$ & 34 & $29(85.3)$ & $5(14.7)$ & & \\
\hline Gender & & & & 0.05 & 0.82 \\
\hline Male & 54 & $50(92.6)$ & $4(7.4)$ & & \\
\hline Female & 46 & $43(93.5)$ & $3(6.5)$ & & \\
\hline Age of start transfusion, months & & & & 0.39 & 0.53 \\
\hline$\leq 9$ & 68 & $62(91.2)$ & $6(8.8)$ & & \\
\hline$>9$ & 32 & $31(96.9)$ & $1(3.1)$ & & \\
\hline Frequency of transfusion, weeks & & & & 1.39 & 0.23 \\
\hline Every 2-3 & 43 & $38(88.4)$ & $5(11.6)$ & & \\
\hline Every 4-5 & 57 & $55(96.5)$ & $2(3.5)$ & & \\
\hline Age of start chelation, years & & & & 0.12 & 0.73 \\
\hline$\leq 3$ years & 73 & 67 (91.8) & $6(8.2)$ & & \\
\hline$>3$ years & 27 & $26(96.8)$ & $1(3.7)$ & & \\
\hline Type of chelators & & & & 3.08 & 0.37 \\
\hline DFX & 19 & $19(100.0)$ & $0(0.0)$ & & \\
\hline DFP & 40 & $36(90.0)$ & $4(10.0)$ & & \\
\hline DFO & 31 & $28(90.0)$ & $3(9.7)$ & & \\
\hline DFO+DFP & 10 & $10(100.0)$ & $0(0.0)$ & & \\
\hline Compliance, $\%$ & & & & 2.00 & 0.15 \\
\hline$<60$ & 69 & $62(89.9)$ & $7(10.1)$ & & \\
\hline$\geq 60$ & 31 & $31(100.0)$ & $0(0.0)$ & & \\
\hline $\begin{array}{l}\text { Mean serum ferritin level } \pm \mathrm{SD} \\
\text { (range), } \mathrm{ng} / \mathrm{ml}\end{array}$ & & $3,398.7 \pm 1,591.2(836-7,830)$ & $5,952.6 \pm 3,022.6(1,026-8,500)$ & 3.80 & $<0.001^{\mathrm{b}}$ \\
\hline
\end{tabular}

${ }^{\mathrm{a}} \mathrm{P}<0.05$; ${ }^{\mathrm{P}}<0.001$. DFX, deferasirox; DFP, deferiprone; DFO, desferrioxamine; SD, standard deviation.

The present study showed that $70 \%$ of patients had evidence of growth retardation.

Similarly, Moayeri and Oloomi (13) reported that short stature was prevalent in $62 \%$ of patients. In addition, Mostafavi et al (14) reported a higher prevalence of growth retardation where $90.9 \%$ of patients were under the fifth percentile.

By contrast, other studies reported a lower prevalence of growth retardation compared to the present study, which ranged from 30 to $50 \%(6,12,15-17)$. Variability in the prevalence of growth retardation in different studies could be attributed to the age of the studied patients, regularity of blood transfusion, type and compliance to iron chelation therapy.

Hypogonadism is a well-recognized complication in thalassemic patients. In the present study, hypogonadism was a complication in $67 \%$ of patients and this was nearly consistent with multiple studies in which Moayeri and Oloomi (13) found hypogonadism in $69 \%$ of thalassemia major patients and Jensen et al (9) reported that $66 \%$ of patients had hypogonadism.
Other previous studies reported a higher prevalence of hypogonadism compared to the present study, which ranged from 70 to $100 \%(6,7,16,18)$. By contrast, other studies reported a lower prevalence of hypogonadism compared to the present study, which ranged from 12 to $54 \%(5,10,19-21)$.

Thyroid dysfunction is known to occur frequently in thalassemia major, but its prevalence and severity varies in different cohorts (22). In the present study hypothyroidism was present in $8 \%$ of patients. Similarly, Shamshirsaz et al (10) reported that the prevalence of hypothyroidism was $7.7 \%$. Other studies have reported a higher prevalence of hypothyroidism, reaching $17-18 \%(23-25)$, while others had reported low prevalence from 0 to $9 \%(26-28)$.

Of note, even in the studies in which the prevalence of overt hypothyroidism as a complication of thalassemia major is relatively low, milder forms of thyroid dysfunction are much more common, although there are wide variations in different studies. These discrepancies can be attributed to differences in the age of patients and different treatment protocols, including differing transfusion rates and chelation therapies (29). 
Table VI. Association between patient genotype and endocrinal complications.

\begin{tabular}{|c|c|c|c|c|c|c|}
\hline Characteristics & $\begin{array}{l}\text { Patients, } \mathrm{n} \\
\quad(\mathrm{n}=100)\end{array}$ & $\begin{array}{c}\beta^{0} \beta^{0}(\mathrm{n}=34) \\
\mathrm{n}(\%)\end{array}$ & $\begin{array}{c}\beta^{+} \beta^{0}(\mathrm{n}=6) \\
\mathrm{n}(\%)\end{array}$ & $\begin{array}{c}\beta^{+} \beta^{+}(\mathrm{n}=60) \\
\mathrm{n}(\%)\end{array}$ & $\chi^{2}$ test & P-value \\
\hline Gender & & & & & 3.71 & 0.15 \\
\hline Male & 54 & $14(25.9)$ & $3(5.6)$ & $37(68.5)$ & & \\
\hline Female & 46 & $20(43.5)$ & $3(6.5)$ & $23(50.0)$ & & \\
\hline Age of start transfusion, months & & & & & 18.60 & $<0.001^{\mathrm{a}}$ \\
\hline$\leq 9$ & 68 & $32(47.1)$ & $5(7.4)$ & $31(45.6)$ & & \\
\hline$>9$ & 32 & $2(6.3)$ & $1(3.1)$ & $29(90.6)$ & & \\
\hline Frequency, weeks & & & & & 79.20 & $<0.001^{\mathrm{a}}$ \\
\hline Every 2 & 34 & $29(85.3)$ & $2(5.9)$ & $3(8.8)$ & & \\
\hline Every 3 & 9 & $2(22.2)$ & $3(33.3)$ & $4(44.4)$ & & \\
\hline Every 4 & 49 & $2(4.1)$ & $1(2.0)$ & $46(93.9)$ & & \\
\hline Every 5 & 8 & $1(12.5)$ & $0(0.0)$ & $7(87.5)$ & & \\
\hline Age of start chelation, years & & & & & 13.05 & $<0.001^{\mathrm{a}}$ \\
\hline$\leq 3$ & 73 & $31(42.5)$ & $6(8.2)$ & $36(49.3)$ & & \\
\hline$>3$ & 27 & $3(11.1)$ & $0(0.0)$ & $24(88.9)$ & & \\
\hline Growth retardation & & & & & 16.35 & $<0.001^{\mathrm{a}}$ \\
\hline Negative & 30 & $2(6.7)$ & $1(3.3)$ & $27(90.0)$ & & \\
\hline Positive & 70 & $32(45.7)$ & $5(7.1)$ & $33(47.1)$ & & \\
\hline Hypogonadism & & & & & 16.09 & $<0.001^{\mathrm{a}}$ \\
\hline Negative & 33 & $3(9.1)$ & $1(3.0)$ & $29(87.9)$ & & \\
\hline Positive & 67 & $31(46.3)$ & $5(7.5)$ & $31(46.3)$ & & \\
\hline Hypothyrodism & & & & & 14.75 & $<0.001^{\mathrm{a}}$ \\
\hline Negative & 92 & $28(30.4)$ & $4(4.3)$ & $60(65.2)$ & & \\
\hline Positive & 8 & $6(75.0)$ & $2(25.0)$ & $0(0.0)$ & & \\
\hline Hypoparathyroidism & & & & & 6.58 & $0.037^{\mathrm{b}}$ \\
\hline Negative & 93 & $29(31.2)$ & $5(5.4)$ & $59(63.4)$ & & \\
\hline Positive & 7 & $5(71.4)$ & $1(14.3)$ & $1(14.3)$ & & \\
\hline Diabetes mellitus & & & & & 0.79 & 0.67 \\
\hline Negative & 92 & $31(33.7)$ & $5(5.4)$ & $56(60.9)$ & & \\
\hline Positive & 8 & $3(37.5)$ & $1(12.5)$ & $4(50.0)$ & & \\
\hline
\end{tabular}

${ }^{\mathrm{a}} \mathrm{P}<0.001 ;{ }^{\mathrm{b}} \mathrm{P}<0.05$.

Hypoparathyroidism in transfusion-dependent patients with $\beta$-thalassemia appears to be accompanied by other endocrinopathies. It is usually a late complication, and occurs after the age of 16 years (30). In the present study the prevalence of hypoparathyrodism was 7\%. Similarly, Shamshirsaz et al (10) reported that the prevalence of hypoparathyroidism was 7.6\%.

Other studies reported a higher prevalence of hypoparathyrodism compared to the present study. Jensen et al (9) and Gulati et al (31) reported that hypoparathyroidism was observed in $13 \%$ of patients. By contrast, Toumba et al (19) reported that the prevalence of hypoparathyrodism was $1.2 \%$, which is low compared to the present study.

Diabetes mellitus is also a frequent complication later in life of thalassemic patients, mainly due to iron overload, chronic liver disease and genetic predisposition (19). In the present study the prevalence of diabetes mellitus was $8 \%$ in patients. In agreement with this study, Najafipour (6) reported that the prevalence of diabetes mellitus was $8.9 \%$. Previous studies have reported a higher prevalence of diabetes mellitus in comparison to the present study, which ranged from 9 to $20 \%(9,19,32,33)$.

The 3 most common mutations in the present study were IVS-1-110, IVS-1-1 and IVS-1-6 (31.5, 23.5 and 20.5\%, respectively). These results corresponded with numerous previous Egyptian studies in which the 3 most frequent mutations in Egyptian thalassemic patients in different parts of Egypt were IVS-1-110, IVS-1-1 and IVS-1-6 (34-39).

Furthermore, Huisman et al (40) found that the most common mutations in Mediterranean areas were IVS-1-110, IVS-1-6, IVS-1-1, promotor 87, IVS-11-745 and C39. Additionally, the most common mutations in Middle East areas were C8, C8/C9, IVS1-5, C39, C44 and IVS11-1.

In the present study growth retardation was significantly prevalent in the older age group $(\mathrm{P}=0.016)$ and there was a significant association between growth retardation and earlier age of 
start transfusion, chelation and frequency of blood transfusion, poor compliance and higher mean serum ferritin level $(\mathrm{P}<0.001$, $\mathrm{P}<0.001, \mathrm{P}<0.001, \mathrm{P}=0.0015$ and $\mathrm{P}<0.001$, respectively).

In agreement with this study, Kirti et al (17), Borgna-Pignatti et al (21) and Cario et al (41) reported that growth abnormalities were more prevalent in older and/or pubertal thalassemic patients.

In the present study hypogonadism was prevalent in the older age group $(\mathrm{P}=0.019)$ and there was a significant association between hypogonadism and earlier age of start transfusion, chelation and frequency of blood transfusion, poor compliance and higher mean serum ferritin level $(\mathrm{P}<0.001$, $\mathrm{P}<0.001, \mathrm{P}<0.001, \mathrm{P}=0.0018$ and $\mathrm{P}<0.001$, respectively). Similarly, Shamshirsaz et al (10) reported a significant difference in the mean serum ferritin level between thalassemic patients with primary amenorrhea, irregular menses, hypogonadism and those without endocrinopathies. Furthermore, Borgna-Pignatti et al (21) reported that hypogonadism was detected less in patients whose serum ferritin was $<2,500 \mathrm{ng} / \mathrm{ml}$.

In the present study hypothyroidism was prevalent in the older age group $(\mathrm{P}<0.001)$ and there was a significant association between hypothyroidism and age of start and frequency of blood transfusion, as well as poor compliance and higher mean serum ferritin level $(\mathrm{P}=0.04, \mathrm{P}=0.002, \mathrm{P}=0.049$ and $\mathrm{P}<0.001$, respectively). Zervas et al (42) reported that hypothyroidism was prevalent among patients in second decade of life.

In the present study a significant association was observed between the prevalence of hypoparathyrodism and age of the patients as well as higher mean serum ferritin level $(\mathrm{P}=0.03$ and $\mathrm{P}<0.001$, respectively). Older age patients are more likely to have hypoparathyrodism. Jensen et al (9) reported a significant association between serum ferritin level and hypothyroidism, as well as hypoparathyrodism, suggesting a central role of iron overload in the development of these complications as serum ferritin level was $>2,000 \mathrm{mg} / \mathrm{l}$. This is also supported by the Italian Working Group who reported that the serum ferritin level was higher in patients with one or more endocrinopathies (8).

In the present study diabetes mellitus was more prevalent in patients who started blood transfusion at an earlier age and were poor compliant with a high serum ferritin level ( $\mathrm{P}=0.04, \mathrm{P}=0.04$ and $\mathrm{P}<0.001$, respectively). Similarly, Najafipour et al (43) reported that the age and transfusion periods are risk factors for developing diabetes and that the amount of transfusion is directly linked to the impaired fasting glucose level. Jensen et al (9) identified a significant association between the age of the patients and prevalence of diabetes; younger age is more likely to have a normal oral glucose tolerance test.

The present study found a significant association between the prevalence of endocrine complications and higher serum ferritin levels of $>3,000 \mathrm{ng} / \mathrm{dl}(\mathrm{P}<0.001)$. In agreement with this study, Toumba et al (19), Gamberini et al (44) and Low (45) reported that multiple endocrinopathies, including hypogonadism, hypothyroidism, hypoparathyrodism and diabetes mellitus, developed later in life and were associated with iron overload, which is one of the main risk factors for developing such complications in addition to poor compliance and early onset of transfusion therapy.

The present results showed that patients with the $\beta^{0} \beta^{0}$ genotype had an earlier age of start transfusion and chelation, as well as more frequent transfusions $(\mathrm{P}<0.001$, $\mathrm{P}<0.001$ and $\mathrm{P}<0.001$, respectively), while patients with the $\beta^{0} \beta^{+}$and $\beta^{+} \beta^{+}$genotypes had a delayed age of start transfusion, chelation therapy as well as less frequent blood transfusions and they had a significantly lower prevalence of growth retardation, hypogonadism, hypothyroidism and hypoparathyrodism.

Similarly, Chern et al (7) showed that the $\beta^{0} \beta^{0}$ genotype was significantly correlated with the age of first blood transfusion and it is an indicator of disease severity. The present results are also supported by Skordis et al (16) who demonstrated a significant association between the $\beta^{0} \beta^{0}$ genotype and frequency of blood transfusion where patients with the $\beta^{0} \beta^{0}$ genotype received more frequent blood transfusion.

The present study found that patients with the $\beta^{0} \beta^{0}$ genotype also had a significantly higher prevalence of growth retardation, hypogonadism, hypothyroidism and hypoparathyroidism $(\mathrm{P}<0.001, \mathrm{P}<0.001, \mathrm{P}<0.001$ and $\mathrm{P}=0.037$, respectively). This is in agreement with Yaman et al (46) who reported that the complication rates were significantly higher in thalassemia major patients with the $\beta^{0} \beta^{0}$ genotype compared to thalassemia intermedia patients with $\beta^{+} \beta^{+}(\mathrm{P}<0.05)$. Similarly, Filosa et al (47) reported that all thalassemic patients with hypogonadism express the $\beta^{0} \beta^{0}$ genotype.

Chern et al (7) also showed that patients with the $\beta^{0} \beta^{0}$ genotype were significantly correlated with the development of hypogonadism (odds ratio=28.50, P=0.002). Similarly, Jensen et al (9) reported a significant association between the $\beta^{0} \beta^{0}$ genotype and development of hypogonadism. Also, Skordis et al (16) demonstrated the influence of $\beta^{0} \beta^{0}$ on the development of hypogonadism and associated it to the difference in the amount of blood transfusion and variability in free iron radicals.

The present study observed that patients with the IVS-11-745/IVS-11-745 genotype had a significantly higher prevalence of diabetes. Similarly, Khalifa et al (33) reported the association of the IVS-11-745/IVS-11-745 genotype and the prevalence of diabetes mellitus, in which $77.7 \%$ of patients with diabetes carry the IVS-11-745/IVS-11-745 genotype.

In conclusion, the present study revealed that endocrinal complications were more common in $\beta$-thalassemia patients with a clear association between genotype and clinical disease severity. A significant association was also identified between the serum ferritin levels and the presence of endocrine complications, emphasizing the important role of iron overload in the development of these complications.

\section{Acknowledgements}

The authors would like to thank all the participants of the present study for their cooperation.

\section{References}

1. Cooley TB and Lee P: A series of cases of splenomegally in children with anemia and peculiar changes. Trans Am Pediatr Soc 37: 29-30, 1925.

2. Olivieri NF: The beta-thalassemias. N Engl J Med 341: 99-109, 1999.

3. Gringras P, Wonke B, Old J, Fitches A, Valler D, Kuan AM and Hoffbrand V: Effect of alpha thalassaemia trait and enhanced gamma chain production on disease severity in beta thalassaemia major and intermedia. Arch Dis Child 70: 30-34, 1994. 
4. Weatherall DJ and Clegg JB (eds.): The Thalassemia Syndromes. 4th edition. Blackwell Science Ltd., Oxford, 2000.

5. De Sanctis V, Roos M, Gasser T, Fortini M, Raiola G and Galati MC; Italian Working Group on Endocrine Complications in Non-Endocrine Diseases: Impact of long-term iron chelation therapy on growth and endocrine functions in thalassaemia. J Pediatr Endocrinol Metab 19: 471-480, 2006.

6. Najafipour F: Evaluation of endocrine disorders in patients with thalassemia major. Int J Endocrinol Metab 2: 104-113, 2008.

7. Chern JP, Lin KH, Tsai WY, Wang SC, Lu MY, Lin DT, Lin KS and Lo SH: Hypogonadotropic hypogonadism and hematologic phenotype in patients with transfusion-dependent beta-thalassemia. J Pediatr Hematol Oncol 25: 880-884, 2003.

8. No authors listed: Multicentre study on prevalence of endocrine complications in thalassaemia major. Italian Working Group on Endocrine Complications in Non-endocrine Diseases. Clin Endocrinol (Oxf) 42: 581-586, 1995.

9. Jensen CE, Tuck SM, Old J, Morris RW, Yardumian A, De Sanctis V, Hoffbrand AV and Wonke B: Incidence of endocrine complications and clinical disease severity related to genotype analysis and iron overload in patients with beta-thalassaemia. Eur J Haematol 59: 76-81, 1997.

10. ShamshirsazAA,BekheirniaMR, KamgarM,Pourzahedgilani N, Bouzari N, Habibzadeh M, Hashemi R, Shamshirsaz AA, Aghakhani S, Homayoun $\mathrm{H}$, et al: Metabolic and endocrinologic complications in beta-thalassemia major: A multicenter study in Tehran. BMC Endocr Disord 3: 4, 2003.

11. Classification and diagnosis of diabetes mellitus and other categories of glucose intolerance. National Diabetes Data Group. Diabetes 28:1039-1057, 1979.

12. Abdulzahra MS, Al-Hakeim HK and Ridha MM: Study of the effect of iron overload on the function of endocrine glands in male thalassemia patients. Asian J Transfus Sci 5: 127-131, 2011.

13. Moayeri $\mathrm{H}$ and Oloomi Z: Prevalence of growth and puberty failure with respect to growth hormone and gonadotropins secretion in beta-thalassemia major. Arch Iran Med 9: 329-334, 2006.

14. Mostafavi H, Afkhamizadeh M and Rezvanfar MR: Endocrine disorders in patients with thalassemia major. Iranian J Endocrinol Metab 7: 143-147, 2005

15. De Sanctis V, Eleftheriou A and Malaventura C; Thalassaemia International Federation Study Group on Growth and Endocrine Complications in Thalassaemia: Prevalence of endocrine complications and short stature in patients with thalassaemia major: A multicenter study by the Thalassaemia International Federation (TIF). Pediatr Endocrinol Rev 2 (Suppl 2): 249-255, 2004.

16. Skordis N, Michaelidou M, Savva SC, Ioannou Y, Rousounides A Kleanthous M, Skordos G and Christou S: The impact of genotype on endocrine complications in thalassaemia major. Eur J Haematol 77: 150-156, 2006

17. Kirti G, Pankaj A, Minakshi V, Ritu Y and Shiksha S: Associated Complications in Beta Thalasemia Patients. IOSR J Pharm 3 : 22-25, 2013.

18. Soliman AT, elZalabany M, Amer M and Ansari BM: Growth and pubertal development in transfusion-dependent children and adolescents with thalassaemia major and sickle cell disease: a comparative study. J Trop Pediatr 45: 23-30, 1999.

19. Toumba M, Sergis A, Kanaris C and Skordis N: Endocrine complications in patients with Thalassaemia Major. Pediatr Endocrinol Rev 5: 642-648, 2007.

20. Rodda CP, Reid ED, Johnson S, Doery J, Matthews R and Bowden DK: Short stature in homozygous beta-thalassaemia is due to disproportionate truncal shortening. Clin Endocrinol (Oxf) 42: 587-592, 1995

21. Borgna-Pignatti C, Rugolotto S, De Stefano P, Zhao H, Cappellini MD, Del Vecchio GC, et al: Survival and complications in patients with thalassemia major treated with transfusion and deferoxamine. Haematologica 89: 1187-1193, 2004.

22. Pantelakis S: Thyroid disorders and diabetes mellitus as complications of thalassaemia major. Acta Paediatr Suppl 406: 111-113, 1994.

23. Landau H, Matoth I, Landau-Cordova Z, Goldfarb A, Rachmilewitz EA and Glaser B: Cross-sectional and longitudinal study of the pituitary-thyroid axis in patients with thalassaemia major. Clin Endocrinol (Oxf) 38: 55-61, 1993.

24. Agarwal MB, Shah S, Vishwanathan C, Rajadhyaksha G, et al: Thyroid dysfunction in multi-transfused iron loaded thalassemia patients. Indian Pediatr 29: 997-102, 1992.

25. Magro S, Puzzonia P, Consarino C, Galati MC, Morgione S, Porcelli D, Grimaldi S, Tancrè D, Arcuri V, De Santis V, et al: Hypothyroidism in patients with thalassemia syndromes. Acta Haematol 84: 72-76, 1990.
26. Depaz G, Deville A, Coussement N, Manassero J and Mariani R: Thyroid function in thalassemia major. Ann Pediatr (Paris) 32: 809-811, 1985 (In French).

27. Phenekos C, Karamerou A, Pipis P, Constantoulakis M, Lasaridis J, Detsi S and Politou K: Thyroid function in patients with homozygous beta-thalassaemia. Clin Endocrinol (Oxf) 20 445-450, 1984

28. Senanayake MP, Suraweera SA and Hubert HD: Thyroid function in thalassaemia major. Ceylon Med J 44: 166-168, 1999.

29. Sabato AR, de Sanctis V, Atti G, Capra L, Bagni B and Vullo C: Primary hypothyroidism and the low T3 syndrome in thalassaemia major. Arch Dis Child 58: 120-127, 1983.

30. DeSanctis V,VulloC,Bagni B and Chiccoli L:Hypoparathyroidism in beta-thalassemia major. Clinical and laboratory observations in 24 patients. Acta Haematol 88: 105-108, 1992.

31. Gulati R, Bhatia V and Agarwal SS: Early onset of endocrine abnormalities in beta-thalassemia major in a developing country. J Pediatr Endocrinol Metab 13: 651-656, 2000.

32. Kurtoglu AU, Kurtoglu E and Temizkan AK: Effect of iron overload on endocrinopathies in patients with beta-thalassaemia major and intermedia. Endokrynol Pol 63: 260-263, 2012.

33. Khalifa AS, Salem M, Mounir E, El-Tawil MM, El-Sawy M and Abd Al-Aziz MM: Abnormal glucose tolerance in Egyptian beta-thalassemic patients: Possible association with genotyping. Pediatr Diabetes 5: 126-132, 2004.

34. Hussein G, Fawzy M, Serafi TE, Ismail EF, Metwally DE, Saber MA, Giansily M, Schved JF, Pissard S and Martinez PA: Rapid detection of beta-Thalassemia alleles in Egypt using naturally or amplified created restriction sites and direct sequencing: a step in disease control. Hemoglobin 31: 49-62, 2007.

35. Jiffri EH, Bogari N, Zidan KH, Teama S and Elhawary NA: Molecular updating of $\beta$-thalassemia mutations in the Upper Egyptian population. Hemoglobin 34: 538-547, 2010.

36. Hussein IR, Temtamy SA, el-Beshlawy A, Fearon C, Shalaby Z, Vassilopoulos $\mathrm{G}$ and Kazazian HH Jr: Molecular characterization of beta-thalassemia in Egyptians. Hum Mutat 2: 48-52, 1993.

37. Novelletto A, Hafez M, Deidda G, Di Rienzo A, Felicetti L, el-Tahan H, el Morsi Z, el-Ziny M, al-Tonbary Y, Sittien A, et al: Molecular characterization of beta-thalassemia mutations in Egypt. Hum Genet 85: 272-274, 1990.

38. Soliman OE, Yahia S, Shouma A, Shafiek HK, Fouda AE, Azzam H, Abousamra NK, Mahfouz R, Goda EF and El-Sharawy SA: Reverse hybridization StripAssay detection of beta-thalassemia mutations in northeast Egypt. Hematology 15: 182-186, 2010.

39. Omar A, Abdel Karim E, Gendy WE, Marzouk I and Wagdy M: Molecular basis of beta-thalassemia in Alexandria. Egypt J Immunol 12: 15-24, 2005

40. Huisman THJ, Carver MFH and Baysal E: Beta-thalassemia; nondeletional mutants. In: A syllabus of thalassemia mutations. Huisman THJ, Carver MFH, Baysal E and Marianne FH (eds). The Sickle Cell Anemia Foundation, Augusta, GA, ppl-309, 1997.

41. Cario H, Stahnke K, Sander S and Kohne E: Epidemiological situation and treatment of patients with thalassemia major in Germany: results of the German multicenter beta-thalassemia study. Ann Hematol 79: 7-12, 2000.

42. Zervas A, Katopodi A, Protonotariou A,Livadas S, Karagiorga M, Politis $\mathrm{C}$ and Tolis G: Assessment of thyroid function in two hundred patients with beta-thalassemia major. Thyroid 12 : $151-154,2002$.

43. Najafipour F, Aliasgarzadeh A, Aghamohamadzadeh N, Bahrami A, Mobasri M, Niafar M and Khoshbaten M: A cross-sectional study of metabolic and endocrine complications in beta-thalassemia major. Ann Saudi Med 28: 361-366, 2008.

44. Gamberini MR, De Sanctis V and Gilli G: Hypogonadism, diabetes mellitus, hypothyroidism, hypoparathyroidism: Incidence and prevalence related to iron overload and chelation therapy in patients with thalassaemia major followed from 1980 to 2007 in the Ferrara Centre. Pediatr Endocrinol Rev 6 (Suppl 1): $158-169,2008$

45. Low LC: Growth, puberty and endocrine function in beta-thalassaemia major. J Pediatr Endocrinol Metab 10: 175-184, 1997.

46. Yaman A, Isik P, Yarall N, Kardemir S, Cetinkaya S, Bay A, Ozkasap S, Kara A and Tunc B: Common complications in Beta thalasemia patients. Int J Hematol Oncol 3: 193-199, 2013.

47. Filosa A, Di Maio S, Vocca S, Saviano A, Esposito G and Pagano L: Longitudinal monitoring of bone mineral density in thalassemic patients. Genetic structure and osteoporosis. Acta Paediatr 86: 342-346, 1997. 